\title{
Malignant cysts of the male breast
}

\author{
W.S.L. Stebbings, B.D. George, Susan Boyle, P.N. Plowman and O.J.A. Gilmore
}

The Breast Unit, St. Bartholomew's Hospital, London EC1A 7BE, UK.

\begin{abstract}
Summary: Two cases of male breast carcinoma presenting as cystic swellings are reported. Cysts of the male breast are rare, but unlike cysts in female breasts are more likely to represent signficant pathology. We recommend consideration of excision biopsy of isolated cysts in male breasts.
\end{abstract}

\section{Introduction}

Carcinoma of the male breast is rare, constituting less than $1 \%$ of all breast cancers. ${ }^{1}$ In 1978 the mortality rate was 3 per million for men compared to 448 per million for women. ${ }^{2}$

Cysts of the female breast are common, although intracystic tumours are very rare. The criteria for treating female breast cysts by simple aspiration are well recognized. ${ }^{3}$ The management of cysts of the male breast is not well established. We here report two cases of male breast carcinoma presenting as cystic swellings.

\section{Case reports}

Case 1

A 71 year old man presented with 2-year history of swelling in the left breast, in association with an intermittent brown discharge from the nipple. On examination there was a $6 \times 6 \mathrm{~cm}$ irregular swelling behind the left nipple. One $\mathrm{ml}$ of blood-stained fluid was aspirated and cytological examination revealed well differentiated adenocarcinoma cells. Chest X-ray, bone scan, liver ultrasound and liver function tests showed no evidence of metastatic disease. A left simple mastectomy and axillary clearance was performed. Pathological examination of the specimen revealed a $4 \mathrm{~cm}$ diameter cyst, within which a tumour was arising from the anterior wall. Microscopic examination showed an intracystic papillary carcinoma surrounded by a compressed layer of fibrous tissue, with no evidence of infiltration (Figure 1). Oestrogen and progesterone receptor estimation was performed on the tumour and was 382 and $279 \mathrm{fmol} / \mathrm{mg}$ cytosol

Correspondence: W.S.L. Stebbings, M.B., B.Chir., F.R.C.S., 1st Fl. Surgery, St. Bartholomew's Hospital, West Smithfield, London EC1A 7BE, UK.

Accepted: 23 April 1987

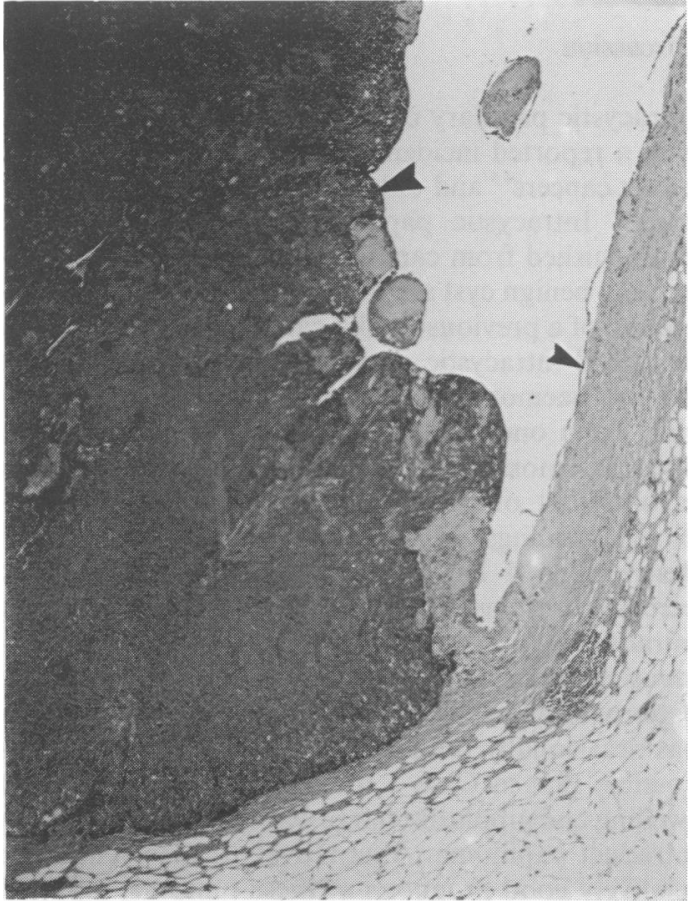

Figure 1 Intracystic papillary carcinoma. Part of the cyst showing a solid mass of tumour cells (large arrow), surrounded by compressed fibrous tissue (small arrow). Haemotoxylin and eosin. Original magnification $\times 35$.

protein respectively. Post-operatively he received radiotherapy $(42.5 \mathrm{~Gy})$ to the left chest wall and gland fields. He remains well after 9 months.

\section{Case 2}

A 66 year old man presented with a 2-month history of a lump in his right breast. On examination there was a

(C) The Fellowship of Postgraduate Medicine, 1987 
$2 \times 2 \mathrm{~cm}$ smooth swelling beneath the right nipple which felt cystic. Following aspiration of $3 \mathrm{ml}$ of blood-stained fluid there was no residual swelling.

Cytology examination of the cyst fluid revealed no malignant cells. At out-patient follow-up, the cyst was again palpable but repeat cytology showed no abnormality. In view of the persistance of the swelling he was admitted for excision biopsy. Pathological examination of the specimen revealed a $0.8 \mathrm{~cm}$ blood-filled cyst. Microscopic examination showed intraduct carcinoma lining the inner surface of the cyst (Figure 2). A right simple mastectomy with axillary clearance was subsequently performed. No evidence of residual tumour was found in the mastectomy specimen and the axillary nodes were not involved. The patient remains free of tumour after 12 months.

\section{Discussion}

Intracystic papillary carcinoma of the breast is rare, with a reported incidence of $0.5-2.0 \%$ of all female breast cancers ${ }^{4,5}$ and only isolated previous reports in men. ${ }^{6,7}$ Intracystic papillary carcinoma should be distinguished from carcinomatous invasion of a preexisting benign cyst and from secondary cystic degeneration of a previously solid carcinoma. Czernobilsky described intracystic papillary carcinoma as a large solitary haemorrhagic cyst, surrounded by a fibrous wall, from one part of which arises a soft papillary adenocarcinoma, with absence of extensive tumour involvement of the surrounding tissue. ${ }^{4}$ The pathological findings in Case 1 are identical to this classical description. It has been suggested that intracystic carcinoma almost always arises from a long standing intraduct papilloma, ${ }^{8}$ and when the tumour becomes invasive it may retain its papillary pattern or adopt the pattern of a ductal carcinoma. Intraduct papilloma has occasionally been reported in male breasts. ${ }^{9}$ It is possible that in Case 1 the long history of a breast swelling and nipple discharge was due to a pre-existing intraduct papilloma. Alternatively it may reflect the relatively good prognosis of these tumours, reported in females. ${ }^{10}$

In Case 2, the cyst was found to be lined by intraduct carcinoma. Breast cysts are thought usually to be derived from lobules and are consequently not a recognized feature of male breasts. It is possible that in Case 2, cystic dilatation occurred secondary to obstruction of a duct by in situ carcinoma. Although the net result was a cystic swelling containing intraduct

\section{References}

1. Axelsson, J. \& Andersson, A. Cancer of the male breast. World J Surg 1983, 7: 281-287.

2. Gardner, M.J., Winter, P.D., Taylor, C.P. \& Acheson, E.D.

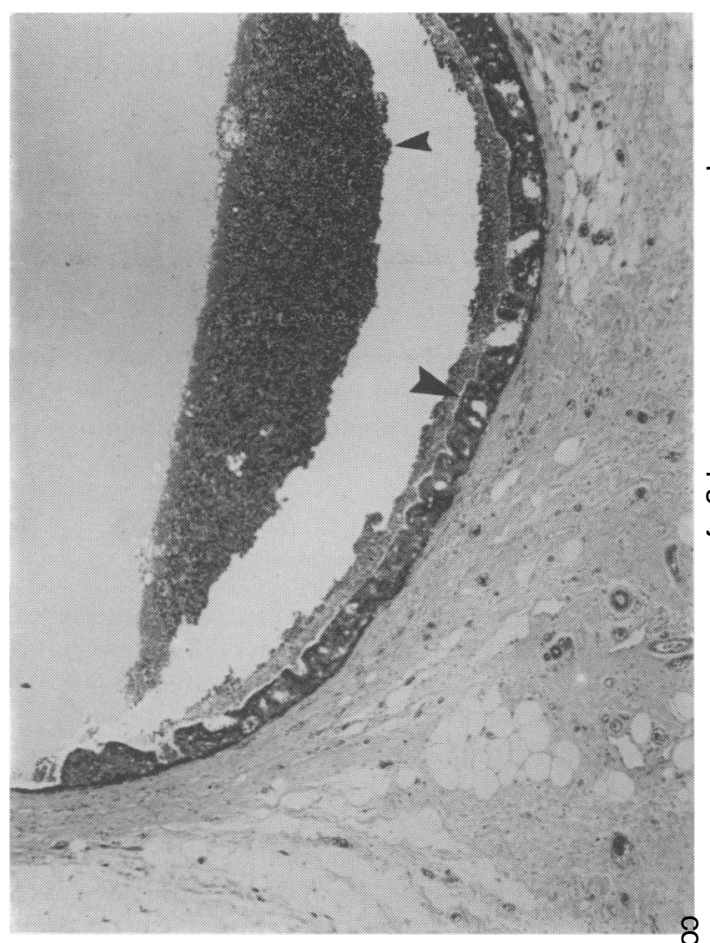

Figure 2 Cyst lined by intraduct carcinoma. Part of the cyst lined by intraduct carcinoma (large arrow) andō. containing blood clot within the lumen (small arrow).? Haemotoxylin and eosin. Original magnification $\times 35$.

carcinoma, this is different to Czernobilsky's classica description of intracystic carcinoma.

The tumour in Case 1 was found to have positive oestrogen and progesterone receptor activity. This is not surprising as male breast carcinoma is usually hormone sensitive. Everson and Lippman reviewed previous publications in male breast cancer and found that $84 \%$ of tumours sampled contained oestrogen receptor activity and $73 \%$ progesterone receptor activity."

In conclusion, cysts of the male breast are rare. We $\frac{D}{0}$ have reported two cases of male breast cysts which proved to be due to malignant disease, and we would $\mathrm{N}$ therefore recommend a high index of suspicion in $N$ dealing with cysts of the male breast.

In Atlas of Cancer Mortality in England and Wales 1968-1978. John Wiley, Chichester, 1983, p 42. 
3. Payne, R.A. \& Jackson, D.B. Cystic tumours of the breast. Ann R Coll Surg Engl 1980, 62: 228-229.

4. Czernobilsky, B. Intracystic carcinoma of the female breast. Surg Gynecol Obstet 1967, 124: 93-98.

5. McKittrick, J.E., Doan, W.A. \& Failing, R.M. Intracystic papillary carcinoma of the breast. Am J Surg 1969, 35: 195-202.

6. Ramos, C.V., Boeshart, C. \& Restrepo, G.L. Intracystic papillary carcinoma of the male breast - immunohistochemical and ultrastructural study. Arch Pathol Lab Med 1985, 109: 858-861.

7. Nocuchi, M., Miwa, K. \& Miyazaki, I. Intracystic carcinoma of the breast in an elderly man. Jpn J Surg 1983, 13: 519-523.
8. Lee, B.M., Intracystic carcinoma of the breast. IMJ 1984, 165: 28-30.

9. Giltman, L. Solitary intraduct papilloma of the male breast. South Med J 1981, 74: 774.

10. Carter, D., Orr, S.L., Merino, M. Intracystic papillary carcinoma of the breast after mastectomy, radiotherapy or excisional biopsy alone. Cancer 1983, 52: 14-19.

11. Everson, R.B. \& Lippman, M.E. Male breast cancer. In McGuire, W.L. (ed) Breast Cancer - Advances in Research and Treatment, Vol. 13. New York Publishing Corporation, New York, 1979. 